\title{
RÉQUIEM PARA AS PEQUENAS LOCALIDADES? REFLEXÕES E PANORAMA DE MUNICÍPIOS DEMOGRAFICAMENTE PEQUENOS
}

\author{
Ângela Maria Endlich \\ Universidade Estadual de Maringá (UEM), Maringá, PR, Brasil \\ amendlich@uem.br \\ Américo José Marques \\ Universidade Estadual de Maringá (UEM), Maringá, PR, Brasil \\ ajmarques74@hotmail.com
}

\begin{abstract}
RESUMO
A instituição do município existe desde a Antiguidade. Acompanhar o percurso dessa históna permite perceber as oscilações quanto ao seu tratamento político ao longo do tempo, entre períodos de autonomia e de sua captura como mera engrenagem administrativa. No Brasil foram poucos os momentos em que os municípios alcançaram maior autonomia, sendo a Constituição Federal de 1988 o mais expressivo deles. Contudo, passadas três décadas as Emendas Constitucionais, regulamentações complementares e novas proposições de lei demonstram novamente uma retração política. Considera-se, nesse artigo, essa realidade articulada a dinâmicas regionais apreendidas em pequenas localidades no atual período, com perda de centralidade e declínio demográfico, que demandam a deliberação de políticas territoriais. No entanto, o que se observa é o contrário. $O$ texto apresenta reflexões sobre a realidade das pequenas localidades, dos municípios enquanto instituições locais e dados que permitirão uma reflexão acerca da realidade deles, não perdendo de vista a sua dimensão social. Parte dos dados e resultados apresentados, tomando por referência mais específica o recorte territorial do Estado do Paraná, tem como objetivo desconstruir narrativas que levam ao tratamento depreciativo dessas pequenas localidades que tendem a ser cada vez mais marcadas por invisibilidades pela dinâmica política e econômica.
\end{abstract}

Palavras-chave: PEC 188/2019. Pequenas cidades/localidades. Declínio demográfico. Viabilidade e sustentabilidade municipal.

\section{REQUIEM FOR SMALL TOWNS? REFLECTIONS AND OVERVIEW ON DEMOGRAPHICALLY SMALL MUNICIPALITIES}

\begin{abstract}
The municipality has existed since Antiquity. Following the path of this story allows us to perceive the fluctuations regarding its political treatment over time, between periods of autonomy and its capture as a mere administrative mechanism. In Brazil, there were few moments when municipalities achieved greater autonomy, with the Federal Constitution of 1988 being the most expressive of them. However, after three decades, the Constitutional Amendments, complementary regulations and new law proposals demonstrate again a political retraction. In this article, we consider this reality articulated with regional dynamics apprehended in small localities in the current period, with loss of centrality and demographic decline, which demand the deliberation of territorial policies. However, what is observed is the opposite. The text presents reflections on the reality of small towns, of municipalities as local institutions and data that will allow a reflection on their reality, without losing sight of their social dimension. Part of the data and results presented, taking as a more specific reference the territorial profile of the State of Paraná, aims to deconstruct narratives that lead to the depreciative treatment of these small localities that tend to be increasingly invisible by political and economic dynamics.
\end{abstract}

Key words: Counties/Municipalities. Small towns. Demographic decline. Municipal viability and sustainability. 


\section{INTRODUÇÃO}

Em 2013 foi publicado um pequeno texto no Geocritq $^{1}$ com título que igualmente remetia ao réquiem para pequenas cidades. $O$ termo réquiem tem etimologia romana com significado de descanso. A primeira palavra no ritual que ela implica, traduzindo para o português, seria repouso. Consiste em uma missa celebrada para pessoas falecidas. Talvez o mais conhecido seja o Réquiem de Mozart, especialmente difundido por meio do filme Amadeus ${ }^{2}$. Há muito são compartilhadas inquietações que pequenas localidades passem por declínio demográfico ou estagnação, sem que nenhuma política territorial procure reverter essa tendência. Monteiro Lobato já se referira a Cidades Mortas (LOBATO, 1995). Será essa a perspectiva das pequenas localidades, especialmente as consideradas periféricas na rede urbana?

Encontra-se essa questão pautada também em texto que trata do território australiano, especificamente sobre o seu interior com pequenas localidades em esvaziamento. Ao passo que existe quem defenda as pequenas localidades, outros falam de eutanásia (COLLITS, 2000).

Essa é uma provocação necessária, pois no momento em que este texto foi escrito, fazemos motivados emergiu um fato novo que agrava muito a tendência esboçada quanto às pequenas localidades. No mês de novembro de 2019 o governo brasileiro expôs entre diversas mudanças a Proposta de Emenda Constitucional 188/2019, que ficou conhecida como PEC do Pacto Federativo BRASIL, 2019). Embora alegue que tem como objetivo descentralizar recursos para estados e municípios, dentre diversos ajustes fiscais, propõeque em janeiro/2025, municípios com até 5 mil habitantes que não comprovarem sustentabilidade financeira até 30/06/2023 serão incorporados pelos de melhores condições.

É matéria em debate e sujeita a tramitações. Observaram-se diversas manifestações referindo-se a questão como o bode na sala. Essa expressão não é, obviamente, nada acadêmica, mas tem sido tão repetida que parece oportuno mencioná-la aqui. Ela é baseada em uma parábola, que figura como uma metáfora para uma proposta polêmica e incômoda. Ela é apresentada com a intenção de ser matéria para negociar e ao ser retirada, reduz tão expressivamente o incômodo que favorece a aprovação do restante das mudanças propostas ao mesmo tempo. Sendo essa a intencionalidade ou não, quem trabalha na perspectiva das pequenas localidades, da escala local e dos municípios conhece a fo rma depreciativa com que esses espaços são tratados. Por isso, é preciso falar dos pequenos municípios, seus significados e papéis.

No estado do Paraná há cerca dois anos o Tribunal de Contas fez proposta similar. O próprio trâmite da regulamentação da EC 15/1996 referente a sistematização dos critérios para alterações territoriais municipais e a averiguação da viabilidade municipal para a criação de novos municípios demonstra uma visão muito negativa deles. Essa matéria tramita há mais de vinte anos, as últimas propostas para sua sistematização possuem critérios bastante exigentes para pleitear emancipações e, ainda assim, foi vetada. Nas entrelinhas lê-se que os municípios são considerados como um mal a ser evitado. $O$ principal argumento, em tempos de austeridade fiscal, está relacionado as despesas públicas. Surpreende aos autores, negativamente, as manifestações de apoio as propostas do governo vistas em comentários nas redes sociais e jornais. Nota-se um pensamento coletivo consoante aos discursos do Estado centralizador existente no Brasil.

Trata-se de matéria complexa, acerca da qual pretende-se construir uma contribuição a mais para reflexão e debate, sem ambição nenhuma de ser o bastante para a interpretação adequada dos fatos e da realidade af eta à questão. Procura-se trazer o olhar a partir das localidades em uma perspectiva ascendente (de baixo para cima), em uma proposta que vem claramente em uma perspectiva contrária e descendente.

Tendo em vista que os municípios correspondem ao enquadramento territorial da escala local, ao trabalhar com pequenas localidades trata-se de uma instituição fundamental. Por isso, acompanha-se

${ }^{1}$ Publicação com o escopo de que pesquisadores fizessem uma versão breve de temas de suas pesquisas com caráter informativo de qualidade para a sociedade. Aqui se refere ao texto com título similar a este artigo (ENDLICH, 2013).

2 Repouso eterno dá-Ihes, Senhor. Que a luz perpétua os ilumine. Tu és digno de hinos, ó Deus, em Sião. E a ti rendemos homenagens em Jerusalém. Pequeno excerto do Réquiem de Mozart. O filme Amadeus é considerado um drama biográfico, dirigido por Milos Forman, em 1984 (AMADEUS, 1984).

Caminhos de Geografia Uberlândia-MG $\quad$ v. 22, n. $82 \quad$ ago./2021 $\quad$ p.138-153 Página 139


o seu percurso na história geral e no Brasil, retomando problematizações, com o intuito de refletir sobre os papéis dos municípios demograficamente pequenos.

Sinaliza-se como objetivo problematizar a forma como vem sendo tratada a instituição do município no Brasil, enfocando especialmente a proposta da PEC no 188/2019 no que tange à supressão de municípios. Para tanto, considera-se o Estado do Paraná como referência empírica. Tal problematização conserva preocupações mais amplas com as tendências da espacialidade e a condição humana e social de vida. Busca-se pensar a questão a partir de alguns questionamentos que são percebidos no âmbito da sociedade e acerca dos quais acredita-se que o conhecimento de dados e argumentações poderá iluminar 0 debate. O texto resulta de parceria estabelecida entre pesquisadores com trabalhos voltados aos espaços não metropolitanos, com enfoque especial a municípios com pequenas localidades urbanas e às técnicas de geoprocessamento utilizadas na elaboração de mapas como ferramenta indispensável na compreensão do espaço geográfico.

Como se trata de um tema polêmico e complexo, adverte-se que embora o artigo traga uma visão municipalista, não se ignora o viés oligárquico frequente no controle da política local. Por isso, é preciso uma ressalva: falam em nome dos municípios diversos interesses. É fundamental ler nos discursos as intenções, pois o que aparentemente pode figurar como convergência, pode representar empenhos opostos. Ademais, não é possível apoiar vícios de gestão e os interesses imediatos da política eleitoreira. A inadequação da forma como se encontra a gestão não é motivo para depreciar a escala local, o município e seus significados.

O artigo está estruturado em três itens. Aborda-se primeiramente as transformações na espacialidade e as pequenas localidades, muito significativas no passado, mas que as dinâmicas econômicas e políticas recentes retraem. Posteriormente, expõe-se o município enquanto instituição, sobretudo no Brasil, em meio a uma série de questionamentos. Em seguida, o último item versa sobre o panorama dos pequenos municípios de modo mais específico quanto ao estado do Paraná, tomando por referência aqueles que poderiam ser extintos em decorrência do seu número de habitantes e volume de arrecadação (inferior a 5 mil habitantes e arrecadação inferior ao estipulado pela referida PEC do Pacto Federativo). Além disso, no panorama estarão incluídos dados relativos aos municípios considerados como potenciais incorporadores dos que poderiam ser extintos, tendo em vista as problematizações consideradas necessárias nesse sentido.

\section{TRANSFORMAÇÕES NA ESPACIALIDADE E AS PEQUENAS LOCALIDADES}

É bastante frequente a referência ao êxodo rural como uma grande tendência demográfica. Este foi realmente um processo amplo e muito significativo enquanto transformação não apenas demográfica, mas territorial, pois os fluxos foram espacializados. Neste sentido, compreende-se que as mudanças na espacialidade que vivenciamos nas últimas décadas vão muito além de êxodo rural. Conforme o campo deixou de ser habitat de significativa parte da população brasileira alteraram-se também os papéis das pequenas cidades. Elas eram localidades centrais que atendiam a densa população residente nos municípios.

Embora muitas delas tenham crescido demograficamente, seus papéis foram profundamente modificados. Houve uma perda de centralidade dessas localidades. Configuram-se cada vez mais nitidamente no território, os espaços de esvaziamento e os espaços de concentração demográfica. Ambos com atributos diferentes, mas com dinâmicas totalmente integradas, pelos fluxos e pelas suas motivações.

Desenvolvida em trabalhos anteriores (ENDLICH, 2009; 2015; 2019), a temática do esvaziamento de municípios no Paraná, levou também a percepção de como essa dinâmica af eta mais de mil municípios por todo o Brasil. Percebe-se, ainda, que tal realidade pode ser encontrada em diversos países. Menciona-se a seguir um pouco a respeito da Espanha e Argentina que os autores acompanham de modo mais efetivo, mas vários outros países possuem dinâmicas similares.

No caso da Espanha, em 2018 o jornal El Mundo fala de metade dos pueblos em risco de desaparecer naquele país (CONDE, 2018). Tal questão é frequentemente lembrada em reportagens que mostram pueblos desertos, com um habitante ou com um casal e situações análogas que chamam muito a 
atenção. A literatura tem contemplado essa temática com livros como La España Vacia (MOLINO, 2016) e Los últimos (CERDÁ,2017). Um filme lançado em 2019 com o título Lo nunca visto, trata de um pueblo de montanha - Fuentejuela de Arriba - que precisa de novos habitantes, se não precisarão ser incorporados pela localidade vizinha e não contarão mais com alguns serviços. É uma comédia que expressa questões afins em localidades pequenas e isoladas (LO NUNCA VISTO, 2019).

Ainda, quanto à Espanha encontram-se mobilizações como Teruel Existe! Teruel consiste em uma província da Espanha em que a densidade demográfica média em alguns pontos é mais baixa que a da Lapônia. Como forma de alertar a dirigentes políticos, documentos em apoio as reivindicações por políticas territoriais referem-se a Lapônia do Sul. O território espanhol expressa nitidamente as tendências anteriormente citadas quanto a espaços em esvaziamento e espaços em concentração, apreendidos por meio da densidade que oscila de menos de um habitante a 27 mil habitantes por quilômetro quadrado. A Lapônia no Norte da Finlândia, conhecida por ser esparsamente povoada, por isso a analogia dos espanhóis, tem 1,24 habitantes por quilômetro quadrado. Ou seja, tem áreas na referida província espanhola com densidade ainda inferior.

A Argentina passa por processos similares, com centenas de pueblos com risco de desaparecimento. Um dos casos mais icônicos da Argentina é a localidade de Patrícios, por sua dinâmica anterior, ponto de apoio da ferrovia que por ela passava. Com a desativação dos ramais ferroviários perdeu não apenas a sua principal forma de acesso que se dava pelo trem, como também a fonte de trabalho e de dinamismo local. Chegou a ter 7 mil habitantes e, em 2010, registrava 745 habitantes (INDEC, 2010). Ou seja, ficou com aproximadamente 10 por cento da população. Suas ruas contam essa história e escancaram essa triste geografia. Embora se destaque esse, são muitos em condições idênticas.

As transformações na espacialidade, de modo geral, e a perda de centralidade de pequenas localidades são decorrentes das dinâmicas econômicas. Na ausência de uma política territorial explícita, tais dinâmicas produzem o espaço de acordo com seus interesses e valores, ainda que humana e socialmente bastante inadequados. Trabalhar com esses processos, remete necessariamente a esse debate das políticas territoriais.

No Paraná, em especial na porção norte do território, as transformações que trouxeram uma economia com uso menos intensivo de trabalho, especialmente com agricultura modernizada ou pecuária extensiva com estabelecimentos agropecuários maiores, alteraram a dinâmica dos pequenos núcleos urbanos. A tendência de mobilidade da população, com as condições atuais, ao que tudo indica prosseguirá. Tal realidade só pode ser modificada com política territorial bem definida. Ao contrário, o enfraquecimento político da gestão desses espaços, acentuará a referida tendência de concentração demográfica, em detrimento do esvaziamento de diversas localidades. Do ponto de vista político, esse processo é reforçado pela centralização política na escala nacional. Entretanto, não só não se apresentam as políticas necessárias para reverter o processo, como emergem inciativas governamentais que acentuarão as dinâmicas demográficas em curso.

\section{O MUNICÍPIO NO BRASIL E ALGUMAS PERGUNTAS}

Para compreender o município como instituição é recomendável estudar seu percurso histórico que vem desde a Antiguidade. Diversos autores contribuem neste sentido (KROPOTKIN, 191?; POSADA, 1979; MEIRELES, 2013; ORDUÑA REBOLLO, 2003; ANDRADE, 1995). Em momentos anteriores, incluímos esse tema em nossas análises (ENDLICH, 2012; 2016), deste modo, pretende-se aqui apenas recuperar as inconstâncias quanto a sua abordagem política.

Com a história aprende-se que a instituição do município vem oscilando entre autonomia e sua captura como mera engrenagem de administração central, sendo que os períodos de maior liberdade foram restritos, embora notáveis.

Foi com o surgimento dos Estados Nacionais que os territórios foram uniformizados com a instituição de municípios, ou equivalentes, ampliando-se numericamente, embora convertidos em partes menos significativas de estruturas mais amplas de governo, com autonomia comprometida.

$\mathrm{Na}$ história brasileira, observa-se ainda mais, foram pouquíssimos os momentos em que houve algum fôlego democrático, momentos que representaram também af astamento do poder central e que alguma 
democracia pode se projetar. Existem pesquisas e publicações que demonstram isso. Cigolini (2000), por exemplo, ao expor os municípios brasileiros em relação a cada constituição, demonstra que no período da ditadura militar ocorreu inclusive uma redução no número de municípios, pois em 1963 eram 4.235 e, em 1965 eram 3.957.

Ao longo do tempo, são recorrentes as desconfianças, ingerências e, portanto, a instabilidade institucional. Embora o município tenha uma história tão longínqua no tempo, o tratamento que recebe vai se modificando de acordo com os interesses.

A Constituição Federal de 1988 que foi considerada municipalista e democrática encontra-se bastante alterada em diversas matérias por meio de Emendas Constitucionais que alcançaram em maio de 2020, mais de cem. Arretche (2009) e Santos (2008) abordam essa questão das Emendas Constitucionais e a fragilização dos municípios. A primeira autora afirma que algumas emendas constitucionais não apenas reverteram os princípios de autonomia em relação aos gastos, como autorizam intervenção da União caso tais dispositivos não fossem cumpridos (ARRETCHE, 2009). Em convergência, Santos (2008) assegura que emendas põem em xeque a autonomia municipal no Brasil.

Especificamente a Emenda Constitucional 15/1996, oito anos após início da vigência da Constituição, suspendeu alterações territoriais, sobretudo novas emancipações (BRASIL, 1996). Condicionava tal processo a uma sistematização por lei complementar que 24 anos após a referida emenda continua pendente, como assinalado na introdução. Municípios que já tinham processos iniciados conseguiram judicialmente sua emancipação, mas atualmente está paralisada a criação de novos municípios.

As propostas de extinção de municípios, bem como a história da tramitação dessa regulamentação possuem em comum a justificativa da austeridade e preocupações de ordem fiscal. Entretanto, tratase de uma vez mais de depreciação da escala local e da instituição que a formaliza: o município. Sobretudo, municípios pequenos e periféricos.

Eles constituem espaços fragilizados, politicamente com pouca visibilidade e são ainda mais desvalorizados com esse processo. Em meio à difusão dessas propostas, parecem pairar algumas questões: O Brasil tem municípios demais? Os municípios gastam demais? O que significou para a sociedade a criação de municípios? Então, o que poderá significar a reincorporação ou fusão ? O que se perde junto com uma autonomia mínima das escalas locais? Só nos resta o réquiem para pequenas cidades ou avançar na forma de gestão e na política? Se os municípios são dependentes de transferências, como poderia ser de outra forma com a estrutura tributária centralizada que de modo similar ao quadro das despesas as receitas da União correspondem a cerca de $60 \%$ da arrecadação? Ademais, deve-se considerar que a legislação prevê que um distrito que sedie uma empresa com volume de arrecadação alto não pode se emancipar para não prejudicar o município sede. Ou seja, quando seriam viáveis, apesar do contexto centralizador, são formalmente impedidos para não prejudicar localidades maiores onde estão inseridos interesses escalares mais amplos.

Procura-se desenvolver na sequência algumas reflexões acerca das questões sinalizadas.

\section{O Brasil tem municípios demais? Os municípios gastam demais?}

Essas ideias estão por trás do tratamento político que temos assistido quanto aos municípios. Em trabalhos anteriores procuramos pensar as dimensões territoriais no Brasil e demais países para conferir se havia proporcionalmente muitos municípios no Brasil (ENDLICH, 2010). Cigolini (2012) realiza exercício similar, considerando área e população em diversos países. Em ambos os casos a constatação é de que, comparativamente, o Brasil não tem municípios demais. Isso não significa que não existam problemas, que talvez fossem necessários municípios em algumas áreas enquanto em outras existe uma compartimentação maior. Contudo, esse é um processo que decorre de uma dinâmica social e não de uma racionalidade matemática, financeira e técnica.

Quanto aos gastos, um olhar para as receitas e despesas públicas brasileiras conduz também a uma desconstrução do pensamento, que parece perpassar o senso comum. A fonte dos dados é o IBGE, quanto às despesas e receitas públicas, tomando por referência o ano de 2018 (Figuras 1 e 2). 
Os 5.570 municípios brasileiros têm $18 \%$ das receitas públicas brasileiras. Na Figura 1 fica nítida a distribuição dos recursos no âmbito dos entes federativos brasileiros e a concentração no governo central.

Considerar os dados relativos às despesas públicas reitera a tendência sinalizada (Figura 2). Na realidade, as despesas nos municípios são ainda meno res que sua participação nas receitas. Com todo o processo de municipalização existente, ainda assim, o conjunto dos municípios brasileiros consomem pequena parcela das receitas públicas. Embora esses dados sejam citados em algumas ocasiões e publicações, parece que não são suficientemente conhecidos.

Figura 1 - Brasil. Receitas públicas, 2018.

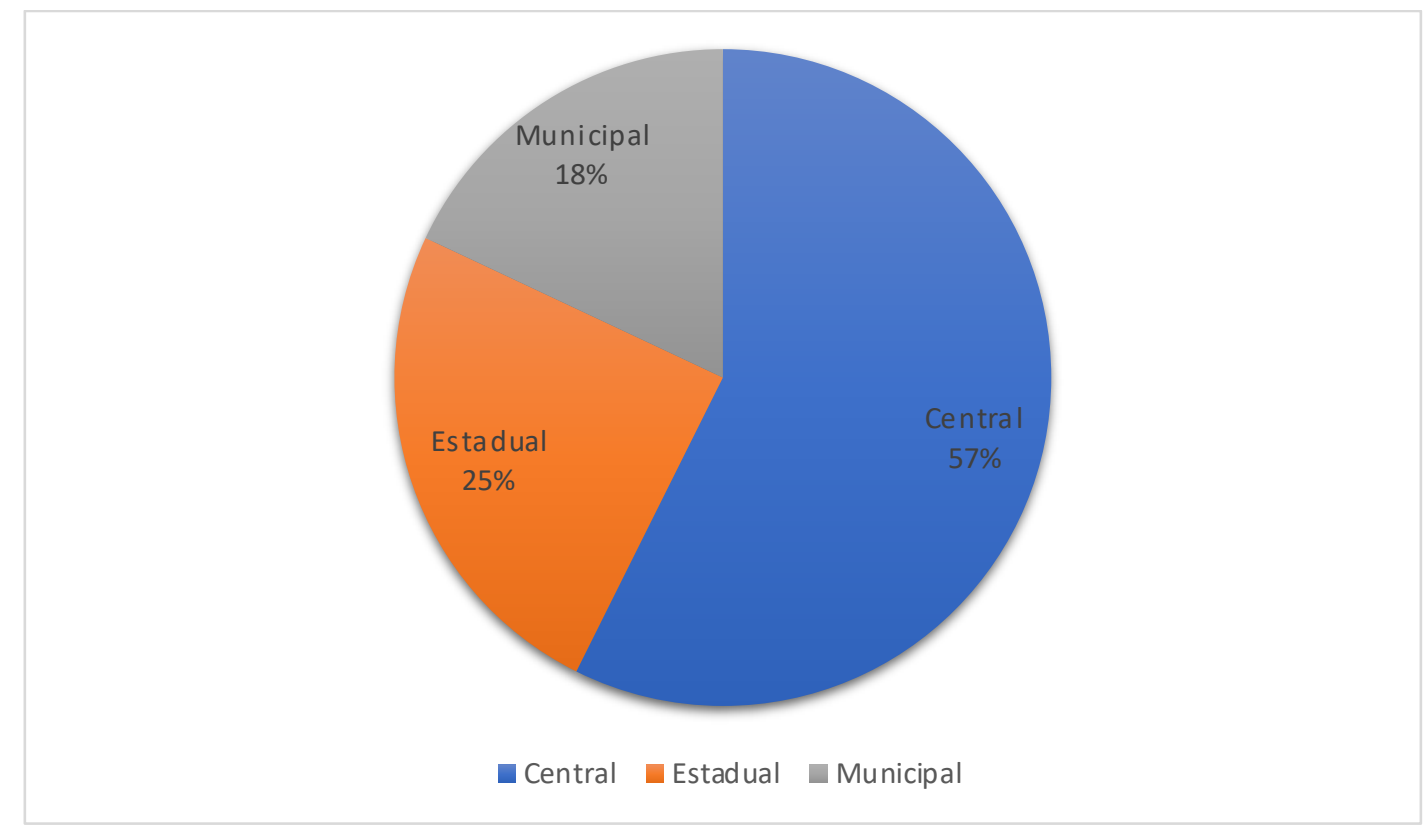

Fonte - IBGE,2018.

Figura 2 - Brasil. Despesas públicas, 2018.

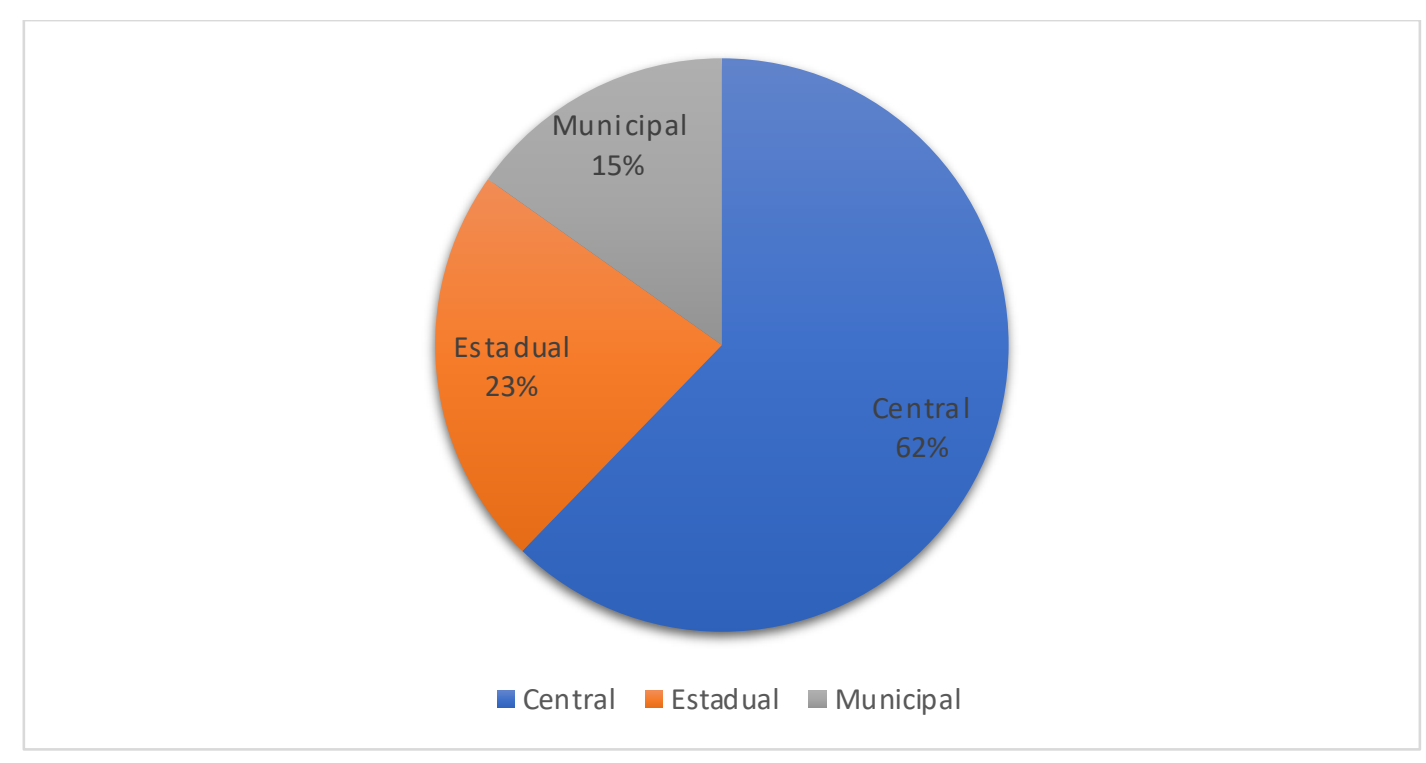

Fonte - IBGE, 2018. 
Muitas análises são possíveis a partir desses dados. O intuito de apresentá-los neste artigo é para responder ao questionamento sinalizado. Os municípios não são os responsáveis pelos gastos mais expressivos no Brasil, ainda mais considerando as atribuições que tem recebido. Para complementar essa análise, é fundamental considerar em que é consumido o orçamento correspondente a União, sobretudo, o fato de que mais de $40 \%$ do orçamento federal é consumido com juros e amortizações da dívida (AUDITORIA CIDADÃ DA DÍVIDA PÛBLICA, 2018).

A publicidade dessa questão é bem inferior ao que deveria ser, ainda que abrangendo um volume enorme de recursos financeiros. É preciso que os dados das finanças públicas como um todo venham a público com transparência. Só assim será possível, ajustar as receitas e despesas públicas de modo devido. Isso não significa que não existam problemas com a condução financeira dos municípios. É preciso pensar formas de inovar na gestão deles, mas se a preocupação é com austeridade e finanças públicas existem outros pontos que deveriam ser priorizados, dado principalmente o volume de recursos envolvidos. Que comecem os questionamentos dessa natureza pela fatia maior, como o faz a Auditoria Cidadã da Dívida Pública. Sem isso, os confrontos serão por migalhas, impondo cortes financeiros que representam maior sacrifício da população.

\section{O que significou para a sociedade a criação de municípios? Então, o que poderá significar a supressão deles e outras questões.}

Enquanto muitos fizeram coro ao discurso centralizador e demonstraram menosprezo pelos municípios novos, uma série de estudos foram realizados com o intuito de averiguar o que esse processo de emancipação de novas localidades representou na perspectiva social, desde a Constituição Federal de 1988. Klering (1998) ao estudar municípios do Rio Grande do Sul, constatou melhorias diversas, especialmente relativas à melhoria de vida da população como saúde e educação. Em trabalhos realizados no Paraná, as constatações são similares (SOUZA, 2016; SANTOS, 2020). Em âmbito mais geral, Arretche (2015) mostra a evolução política e institucional brasileira, preocupada com as desigualdades sociais e territoriais e a necessidade de subsidiar políticas públicas. Ela ressalta as mudanças no país nos últimos quarenta anos, em contraposição a aus ência de serviços básicos água, esgoto e energia elétrica na década de 1970, bem como baixos níveis de escolaridade generalizados em quase todo o território nacional. Houve significativa melhora nas condições de vida nas cidades brasileiras, embora persistam desigualdades.

Para abordar as implicações acerca do que representaria uma política de extinção de municípios demograficamente pequenos, é preciso ter em conta o que representou a institucionalização deles na perspectiva social. Eliminar tenderá a representar, no mínimo, o contrário. Portanto, se diversos trabalhos mostram um avanço para a sociedade na institucionalização de municípios, apesar de todos os problemas, isso deve servir para prever o que aconteceria com a supressão deles. Assinala-se, então, duas outras questões: o que se perde junto com a autonomia mínima das escalas locais? Aderese ao réquiem para pequenas cidades ou procura-se avançar na forma de gestão e na política? A política territorial será a espontaneamente produzida pela dinâmica econômica que muito provavelmente representará a eutanásia das pequenas localidades ou será possível a valorização delas pelos seus significados sociais e culturais?

É certo que com a extinção de municípios, inviabiliza-se ainda mais que pequenas localidades nãometropolitanas possam se manter como espaços de reprodução social; como espaços com oportunidades e serviços mínimos. Se as pequenas localidades periféricas se tornam cada vez menos viáveis como espaços de vida, reforça-se a migração e, por conseguinte, a tendência indesejável de crescimento de grandes periferias urbanas pobres. Deste modo, enquanto a população concentra-se em poucos pontos do território, o restante dele fica refém de interesses econômicos, frequentemente forâneos. Com isso, o patrimônio natural e principalmente cultural pode se perder. Enfim, agravam-se os chamados desequilíbrios territoriais e tendem a piorar as condições humanas e sociais de vida tanto nas espacialidades decorrentes da concentração quanto naquelas que vivenciam estagnação e declínio. A instituição do município garante uma política territorial mínima para áreas periféricas e nãometropolitanas como viabilizar serviços básicos. A cooperação intermunicipal tem avançado entre pequenas localidades possibilitando melhorar o acesso aos serviços e representatividade.

\section{PANORAMA DOS PEQUENOS MUNICÍPIOS DO PARANÁ}

Embora o objetivo deste item seja traçar um panorama dos pequenos municípios do Paraná (Figura 3), isso foi elaborado tendo em consideração um contexto determinado que foi o sinalizado anteriormente, quanto ao artigo 115 da Proposta de Emenda Constitucional 188/2019 (BRASIL, 2019) ${ }^{3}$. Ele propõe que os municípios de até 5 mil habitantes deverão comprovar, até o dia 30 de junho de 2023, sua

${ }^{3}$ A matéria encontra-se com o relator (Senador Márcio Bittar) na Comissão de Constituição, Justiça e Cidadania, desde novembro de 2019. Desde então tem recebido diversas emendas encam inhadas ao referido relator. (BRASIL, 2020) 
sustentabilidade financeira. De acordo com essa proposta, entende-se que a sustentabilidade financeira é atestada mediante a comprovação de que o respectivo produto da arrecadação dos impostos a que se refere o artigo 156 da Constituição Federal (Imposto Predial e Territorial Urbano IPTU, O Imposto de Transmissão de Bens Imóveis Inter-Vivos a qualquer título, por ato oneroso, de bens imóveis, por natureza ou acessão física, e de direitos reais sobre imóveis, exceto os de garantia, bem como cessão de direitos a sua aquisição - ITBI e Imposto Sobre Serviços - ISS) corresponda a, no mínimo, dez por cento da sua receita.

Figura 3 - Paraná. Municípios que poderiam ser extintos, 2020.

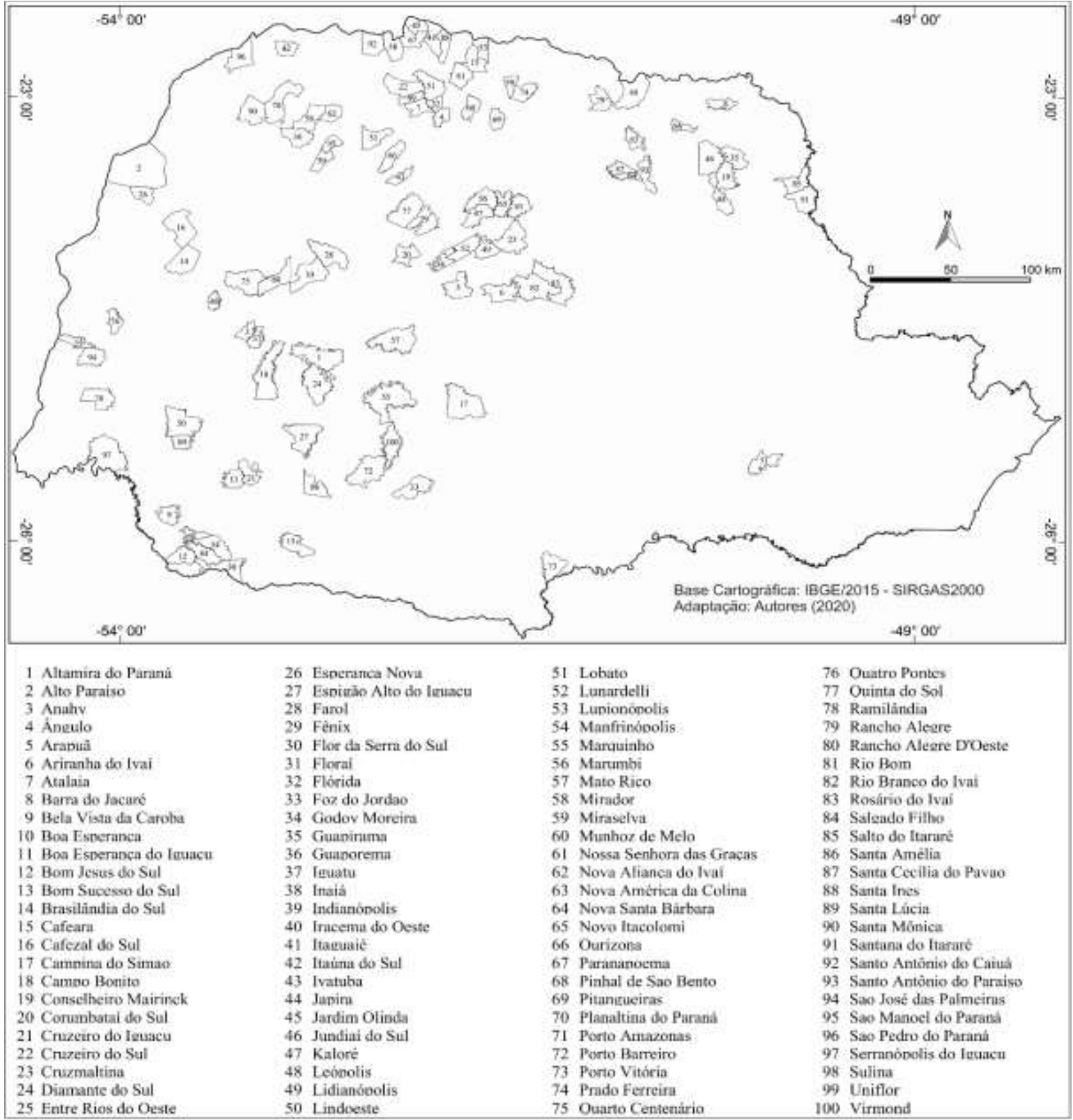

Caso a referida proposta seja aprovada, seriam extintos, no Brasil, mais de 1.200 municípios que estão enquadrados nessa proposta, sem levar em consideração as idiossincrasias locais e a opinião da população diretamente envolvida através de plebiscito. Somente no Paraná cem deixariam de existir de maneira autônoma (Figura 3), o que representa $25 \%$ do total de municípios que compõem o Estado, abarcando tanto municípios mais antigos como municípios criados posteriormente a Constituição de 1988 (Figura 4) (BRASIL, 1988). 
A justificativa para a supressão, de acordo com a proposta, é que os municípios que não arrecadam receitas próprias suficientes para custear a sua própria estrutura (Prefeitura, Câmara de Vereadores etc.), não teriam esses custos (ou seriam substancialmente reduzidos) caso fossem incorporados a outros. Arraigada a essa justificativa dada pelo poder público federal, que propõe essa alteração no arranjo administrativo municipal no País, podem ser formuladas outras tantas questões: será que não deve ser considerado o anseio popular dos cidadãos que habitam esses municípios? Será que outras arrecadações além dos quais se refere o artigo 156 da Constituição Federal não deveriam ser levados em consideração? Esses pequenos municípios gastam mais do que arrecadam? Os municípios incorporadores são sustentáveis financeiramente de acordo com o que prega a Proposta de Emenda Constitucional 188/2019(BRASIL, 2019)? Será que esses municípios, com a extinção, seriam ef etivamente assistidos pelos municípios incorporadores? Em outras palavras, será que os recursos economizados com a extinção das prefeituras e câmaras de vereadores iriam voltar para os munícipios incorporadores e aplicados aos seus novos distritos?

Figura 4 - Paraná. Municípios paranaenses fundados anterior e posterior a CF1988.

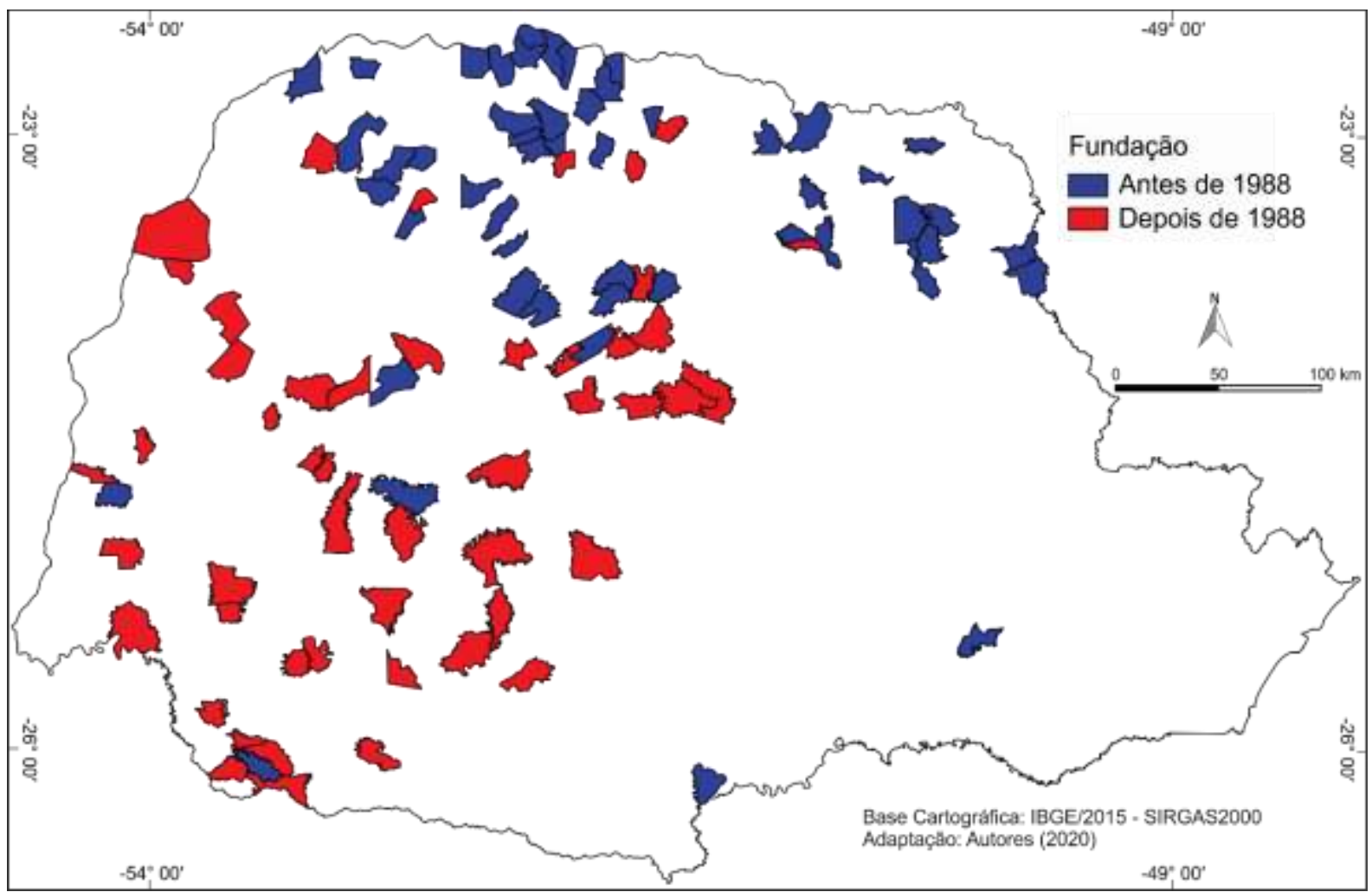

Essas e, possivelmente, outras inquietações serão contempladas na sequência do texto, conforme prossegue o panorama dos cem municípios que correm o risco de ser extintos e serem incorporados por outros no estado do Paraná.

\section{Não deve ser considerado o anseio popular dos cidadãos que habitam nos municípios?}

Inicialmente, é fundamental lembrar que a Constituição Federal de 1988, em seu artigo 18 defende a autonomia municipal dentro da organização político-administrativa da República Federativa do Brasil. Mais especificamente, no inciso $4^{\circ}$ prega que

§ 4ำ A criação, a incorporação, a fusão e o desmembramento de Municípios, far-seão por lei estadual, dentro do período determinado por Lei Complementar Federal, e dependerão de consulta prévia, mediante plebiscito, às populações dos Municípios envolvidos, após divulgação dos Estudos de Viabilidade Municipal, apresentados e publicados na forma da lei (BRASIL, 1988, p. 25). 
É relevante notar dois aspectos inerentes a este inciso. O primeiro se refere primordialmente ao anseio popular, pois seria através da consulta prévia à população envolvida, mediante plebiscito, que municípios poderiam ser criados, incorporados, fundidos ou desmembrados de outros municípios. Deste modo, parece que essa proposta não respeita a constituição quanto a levar em consideração o desejo dos cidadãos que moram nesses municípios, possíveis alvos da extinção.

O outro aspecto que deve ser considerado são os Estudos de Viabilidade Municipal aos quais se referem o referido inciso. Em 2015 foi elaborado o Estudo de Viabilidade Municipal no Paraná tendo em vista discussões na ocasião sobre a criação de novos municípios. O objetivo principal desse relatório foi realizar estudos acerca da viabilidade ou inviabilidade dos municípios existentes e possível ocorrência de novas emancipações municipais no território paranaense, considerando as dimensões econômico-financeira, político-administrativa e socioambiental. Uma das conclusões a que se chegou com esse relatório foi que

na atual conjuntura não se deve criar mais problemas, mas sim soluções aos anseios da sociedade, a qual espera prestação de serviços públicos de qualidade. Assim, deve-se incentivar os Municípios outrora consolidados sem atendimento aos estudos de viabilidade municipal a se conformarem a estes. Aos novos Municípios deve-se exigir critérios rígidos e eficazes, capazes de propiciar sustentabilidade e conômicofinanceira, político-administrativa e socioambiental (FERNANDES et al, 2015, p. 119).

$\mathrm{Na}$ época, pelo que mostrou esse pequeno trecho, não se cogitava extinguir os municípios já implantados que não atingissem 5 mil habitantes e que não alcançassem a arrecadação mínima de $10 \%$ em relação à arrecadação total referente aos impostos assinalados. O referido estudo, pressupunha o incentivo a esses municípios para que eles pudessem prestar serviços públicos de qualidade à sua população. No que tange à criação de novos municípios, esses sim teriam que passar por estudos de viabilidade para comprovar tanto a sustentabilidade econômico -financeira como políticoadministrativa e socioambiental para a sua implantação. Na realidade, a preocupação em estabelecer critérios mínimos deveriam ter ocorrido logo após a Constituição Federal. Por outro lado, o fato de isso não ter acontecido não pode levar a um tratamento inadequado para os municípios constituídos.

\section{Será que outras arrecadações além das quais se refere o artigo 156 da Constituição Federal não deveriam ser levadas em consideração?}

Além dos tributos a que se refere a PEC 188 de 2019, os municípios também recebem recursos oriundos da União e dos estados. Destacam-se desses o ICMS (Imposto sobre Circulação de Mercadorias e Serviços) e o FPM (Fundo de Participação dos Municípios). O ICMS é um imposto, cobrado parcialmente na origem (local onde o bem ou serviço foi produzido) e parcialmente no destino (onde o bem ou serviço foi consumido), sendo de competência estadual. O ICMS é o imposto que gera o maior volume de receitas no País (MENDES; MIRANDA; COSIO, 2008). O FPM, segundo os autores, é uma transferência redistributiva, paga pela União a todos os municípios do País. Trata-se da segunda maior categoria de transferências, perdendo apenas para o repasse do ICMS dos estados para os municípios.

Conforme expresso na Figura 5, ambos representam aproximadamente 93\% de toda a receita recebida pelos municípios paranaenses. As demais fontes de receita, incluindo os tributos a que se refere a PEC do Pacto Federativo (IPTU, ITBI e ISS), chegam somente a $7 \%$ de toda a arrecad ação atribuída aos municípios do estado do Paraná. Não é inadequado pensar que os repasses precisam ser considerados, pois os municípios são parte de uma federação marcada por uma forte centralização, incluindo a captação das receitas públicas, conforme ap resentado anteriormente.

Levando-se em consideração os cem municípios do Paraná que correm o risco de serem extintos, aproximadamente $75 \%$ deles têm o ICMS e o FPM como fonte de receita superiores a $40 \%$ do total de 
arrecadação (Figura 6). Cabe destacar, por exemplo, o município de Santa Inês que apresenta uma arrecadação de aproximadamente $68 \%$ quando consideradas essas duas fontes de receita municipal. É relevante frisar que, conforme já descrito, o ICMS é um imposto sobre a produção e o consumo do bem produzido ou do serviço prestado. A fatia gerada em arrecadação tanto da produção quanto do consumo é concretizada dentro do município.

Figura 5 - Paraná. Fontes de Receitas dos Municípios, 2018.

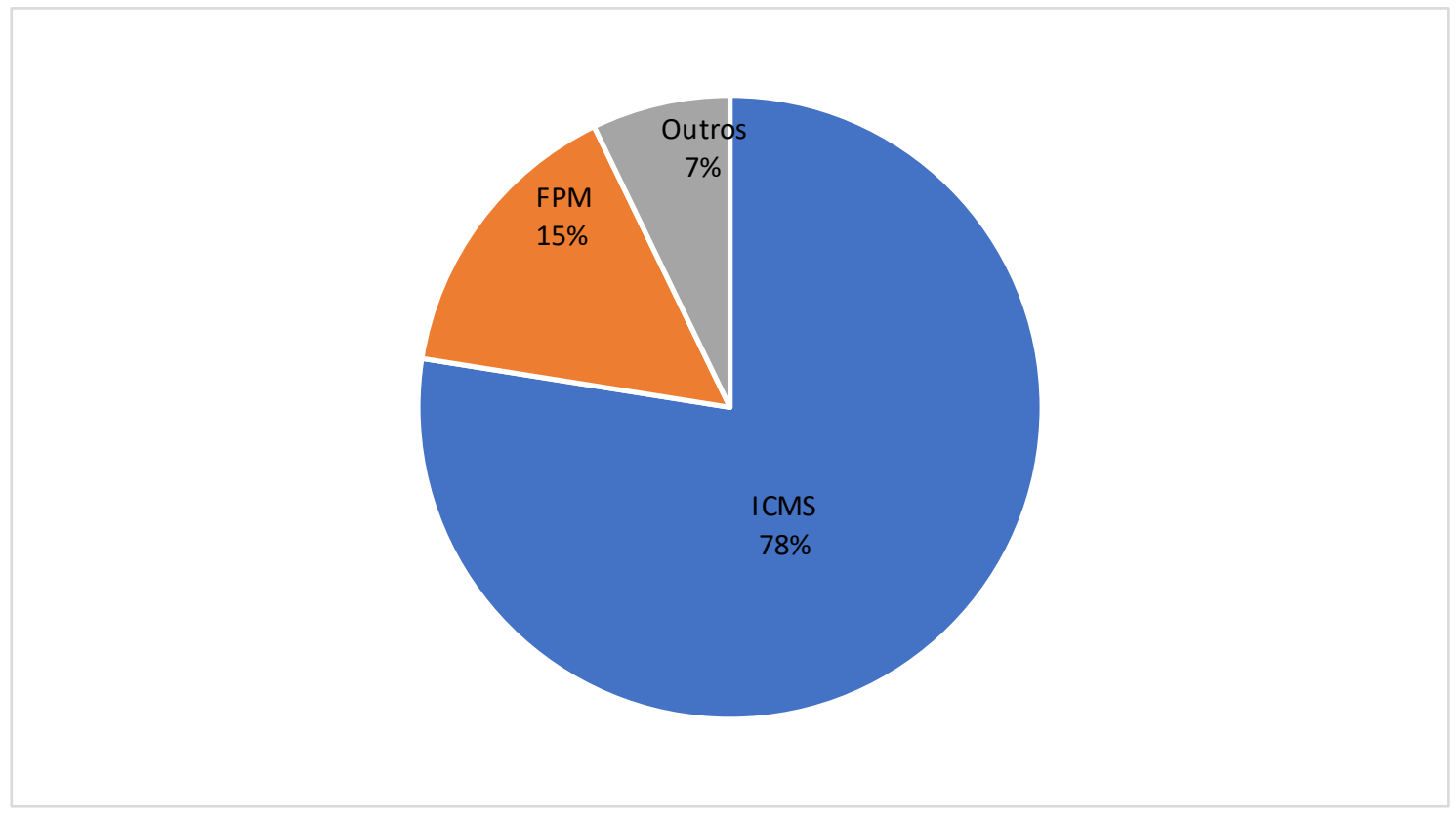

Fonte - IPARDES (2019)

Figura 6 - Paraná. Box plots do percentual do ICMS e do FPM na receita dos municípios. 2018.

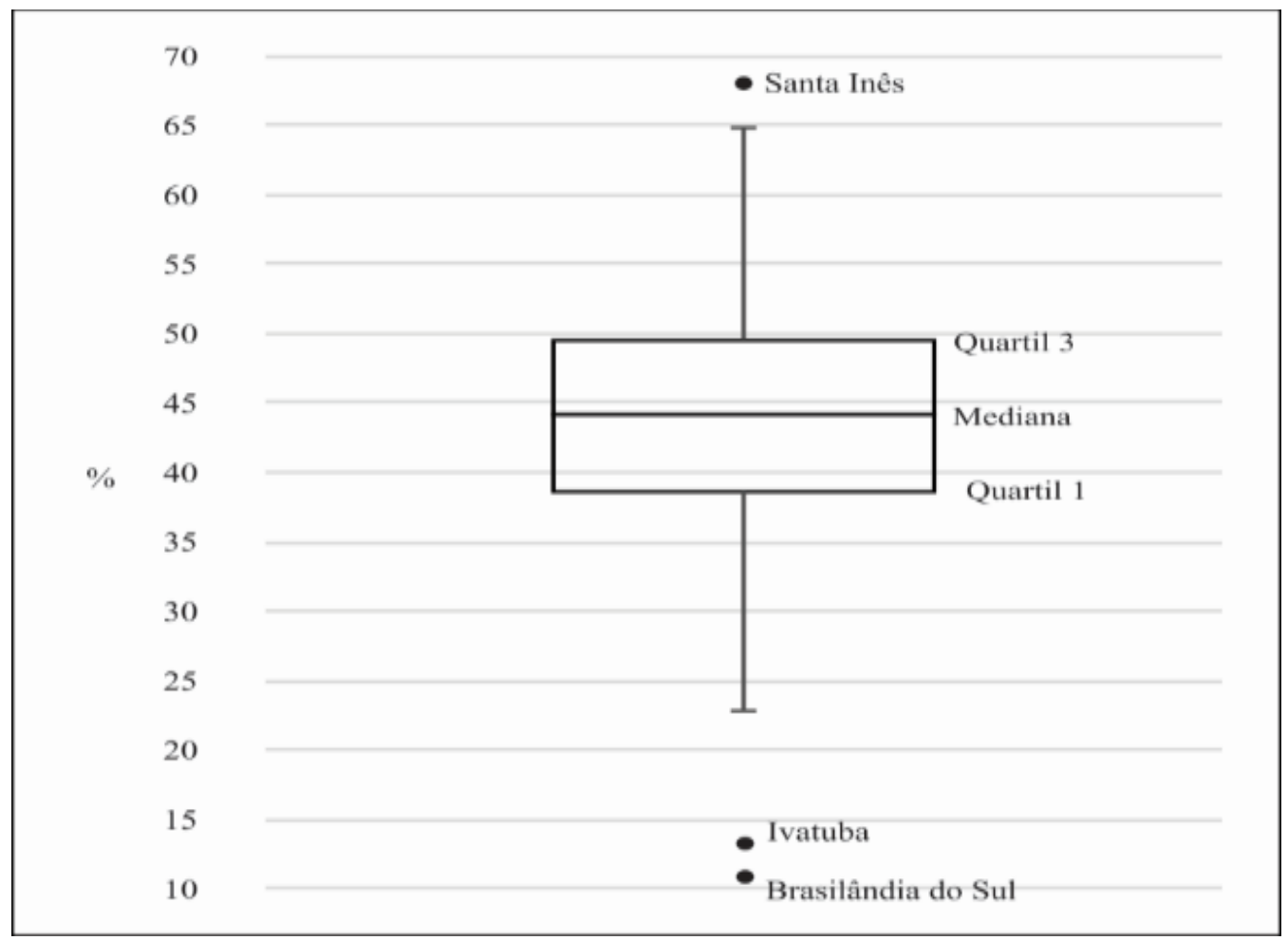

Fonte - IPARDES (2019). 
Ainda sobre a questão do FPM, é preciso lembrar que o repasse realizado pela União é direcionado a todos os municípios do País, seja ele capital ou do interior. O valor repassado é definido de acordo com o coeficiente de participação dos municípios nesse fundo de acordo com a faixa de habitantes desses entes federativos.

No caso, em 2019, o valor repassado para cada um dos municípios de até 10.188 habitantes foi de $R \$$ 8.204.426,28 (primeira faixa do FPM); municípios com população entre 10.189 e 13584 habitantes (segunda faixa do FPM), o repasse foi de $\mathrm{R} \$ 10.939 .234,96$ (IPARDES, 2019).

Analisando somente essas duas faixas de habitantes, pode-se verificar algumas questões relacionadas ao município incorporador, sendo que o mesmo pode permanecer na mesma faixa populacional ou passar para outra faixa, dependendo da população do município a ser incorporado. Como um dos critérios para a supressão é o município ter menos que 5 mil habitantes, o que pode ocorrer é que o município incorporador, tendo população superior ao do referido critério, porém inferior aos 10.189 habitantes, permaneça na primeira faixa do FPM. Isto significa que, mesmo com a incorpo ração, o município incorporador continuaria recebendo o mesmo valor que antes da incorporação.

No segundo caso, mesmo que o município incorporador passe para a segunda faixa do FPM com a incorporação do município extinto, ele passaria a receber o valor de $R \$ 10.939 .234,96$. Se os mesmos permanecem independentes um do outro, a soma do FPM daria $R \$ 16.408 .852,56$, o que representa uma diferença de $R \$ 5.469 .617,60$, uma perda de mais de $33 \%$ da receita do fundo. Tanto no primeiro caso, onde não houve o aumento do repasse, como nesse segundo caso, que apesar de haver o aumento do repasse, porém haver uma perda significativa da receita, podem gerar problemas gravíssimos no que diz respeito da oferta de serviços públicos essenciais à população.

Conforme destacam Mendes; Miranda; Cosio (2008), o FPM é de uso incondicional, obrigatória e sem contrapartida dos municípios, ou seja, qualquer que seja a dimensão populacional, é uma transferência obrigatória e representativa para a manutenção das despesas geradas no município.

\section{Pequenos municípios gastam mais do que arrecadam?}

Para responder a essa pergunta, foi elaborada a Figura 7. Nela foi considerado o balanço financeiro entre as receitas e as despesas dos pequenos municípios no ano de 2018, incluindo o percentual do ICMS e do FPM na receita dos municípios paranaenses.

Figura 7 - Paraná. Balanço Receita/Despesa e resultados, 2019.

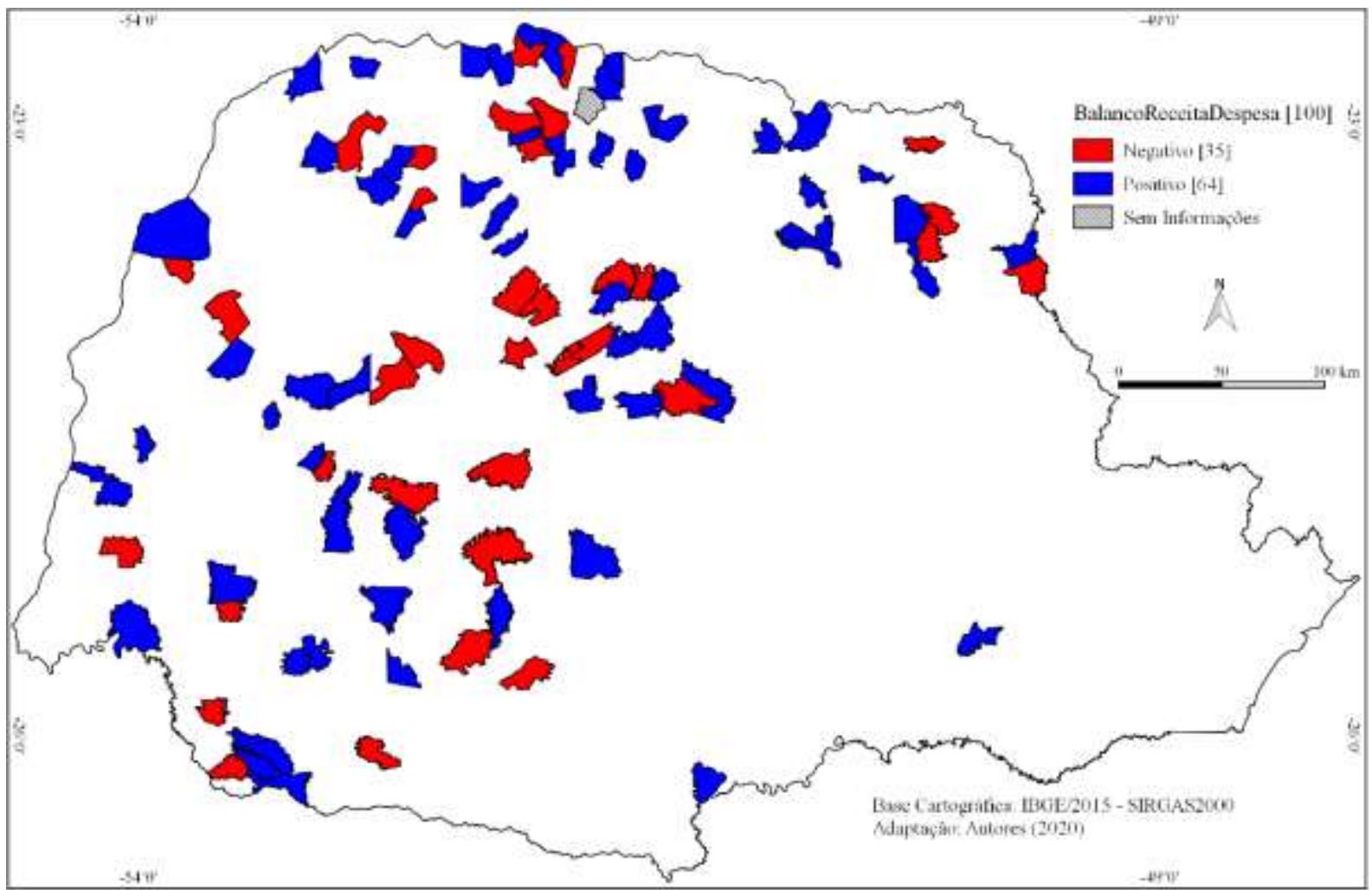

Fonte - IPARDES (2019) 
A figura mostra que $65 \%$ dos pequenos municípios com até 5 mil habitantes têm suas receitas superiores às despesas, fato que não ocorre, conforme será mostrado na questão a seguir os municípios aos quais possivelmente poderiam ser incorporados os municípios menores.

\section{Os municípios possivelmente incorporadores são sustentáveis financeiramente de acordo com o que prega a Proposta de Emenda à Constituição 188/2019?}

A esse questionamento adiciona-se outro a ser analisado e que leva em consideração as condições do município potencialmente incorporador. A referida proposta de EC, apresenta no artigo 115, em seus parágrafos $3^{\circ}$ e $4^{\circ}$ :

\section{$\S 3^{\circ}$ O Município com melhor índice de sustentabilidade financeira será o incorporador $\S 4^{\circ}$ Poderão ser incorporados até três Munícipios por um único Município incorporador (BRASIL, 2019, p. 16).}

Observa-se que a referida proposta não considera nem mesmo a história territorial anterior, pois os municípios não necessariamente retornariam ao município-mãe, mas sim poderiam ser incorporados em algum próximo por razões financeiras. Contudo, de acordo com dados expostos a seguir, a ref erida sustentabilidade financeira não necessariamente está relacionada a tamanho demográfico.

Nesse sentido, alguns aspectos são fundamentais no debate de possíveis incorporações. A Figura 8 apresenta um recorte do Estado mostrando alguns municípios que poderiam ser incorporados e alguns municípios potenciais incorporadores na região norte do Paraná. Nota-se nesse recorte que existem municípios potenciais incorporadores que, tal qual ocorre com os municípios a serem incorporados, igualmente não atingem a arrecadação mínima de $10 \%$ exigido pela referida PEC.

Somente neste recorte, pode-se verificar que dos 19 municípios a serem incorporados, dez deles (Inajá, Paranapoema, Jardim Olinda, Itaguajé, Santa Inês, Lupionópolis, Cafeara, Nossa Senhora das Graças, Lobato e Miraselva) seriam incorporados a municípios que, segundo o Sistema de Informações Contábeis e Fiscais do Setor Público Brasileiro (Siconfi) do Tesouro Nacional, não atingiram, em 2018, o mínimo da arrecadação proposta pela PEC. Ora, se esses municípios candidatos a incorporadores não possuem arrecadação mínima exigida, seriam eles capazes de "cuidarem" do novo ou dos novos entes na mesma situação dando a eles as mesmas condições em que se encontram atualmente independentes? Em outras palavras, será que os recursos economizados com a extinção das prefeituras e câmaras de vereadores iriam voltar para os munícipios incorporadores e aplicados aos seus novos distritos?

Figura 8 - Paraná. Municípios de acordo com arrecadação quanto aos 10 \% da receita total nos impostos. 2018.

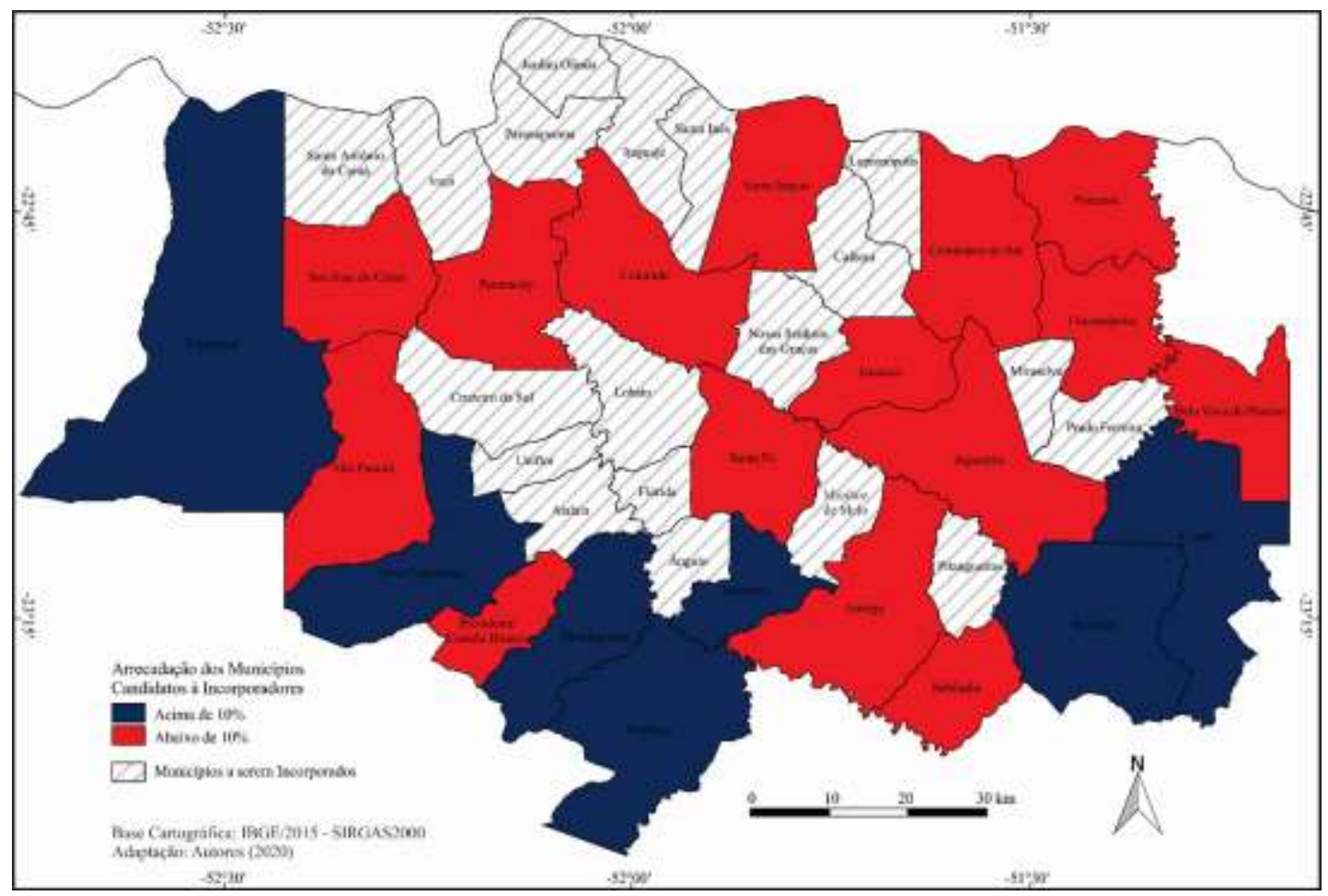

Fonte - Brasil (2018). 
O artigo foi iniciado com muitas questões e termina com mais algumas. Isto indica que o debate promove inquietações diversas. Espera-se ter apresentado parte das que são pertinentes, ao lado de dados a serem considerados. Contudo, sabe-se que outras tantas devem emergir. Lidar com o território, com a realidade social e dinâmicas sociais nele existentes não pode se resumir a propostas tão rasas e equivocadas. $\mathrm{O}$ olhar a partir da perspectiva histórica das instituições locais e a partir da realidade das localidades atuais demonstram que é preciso ter conhecimento quanto a elas para que as intervenções possam ser acertadas e profícuas.

\section{CONSIDERAÇÕES FINAIS}

Dentre tantos questionamentos e incertezas, encerra-se este texto com o convencimento de que é fundamental pesquisar pequenas localidades e os municípios de modo concreto para construir uma interpretação dos seus significados e papéis. Isto não pode ser pensado desde perspectivas centralizadas e tomando por parâmetros uma matemática financeira pautada por interesses que nos remetem a questão da austeridade fiscal. Certamente há um longo caminho para melhorar a gestão política local, mas desacreditar os municípios, do ponto de vista social é muito nocivo.

Como pode-se observar são muitas as fragilidades e incoerências na referida proposição da Emenda Constitucional 188/2019 (BRASIL, 2019). O panorama apresentado quanto aos municípios possivelmente atingíveis demonstra parte desses problemas. Tal fato associado a problematização sinalizada anteriormente, demonstra que o debate precisa ser muito mais amplo. Se a questão é fiscal, temos questões mais graves a tratar no âmbito nacional, como também sinalizamos antes.

Há certamente muito a ser melhorado na gestão dos municípios, talvez seja preciso repensar a forma de administração, visando maior transparência e controle social, possibilidades para reduzir os custos e a eficiência. Contudo, extinguir municípios não parece ser estratégia pertinente para responder as questões das finanças públicas e muito menos constitui estratégia territorial adequada.

\section{REFERÊNCIAS BIBLIOGRÁFICAS}

AMADEUS. Direção Milos Forman. Berleley/EUA - The Saul Zaentz Company. Distribuidora Orion Pictures Corporation Warner Bros, 1984. 1 filme (161 min), son., color.

ANDRADE, M. C. A questão do território no Brasil. São Paulo: Hucitec, 1995, 135 p.

ARRETCHE, M. Continuidades e descontinuidades da Federação Brasileira: de como 1988 facilitou 1995. Dados, v.52, n. 2, p. 377-423, 2009. https://doi.org/10.1590/S0011$\underline{52582009000200004}$

Trazendo o conceito de cidadania de volta: o propósito das desigualdades territoriais. In: ARRETCHE, M. (organizadora). Trajetórias das desigualdades: como o Brasil mudou nos últimos cinquenta anos. São Paulo: Editora da Unesp, 2015, p. 193-222.

AUDITORIA CIDADÃ DA DÍVIDA PÚBLICA. Site de Associação, sem fins lucrativos que tem como principal objetivo realizar, de forma cidadã, auditoria da dívida pública brasileira. 2018. Disponível em: https://auditoriacidada.org.br/. Acesso em: 12. maio 2020.

BRASIL. Constituição da República Federativa do Brasil de 1988. Disponível em $<$ http://www.planalto.gov.br $>$. Acesso em: 23 out. 2020.

BRASIL. Constituição da República Federativa do Brasil. Dá nova redação ao $§ 4^{\circ}$ do art. 18 da Constituição Federal. Emenda Constitucional 15 de 12 de setembro de 1996. Diário Oficial da União: República Federativa do Brasil. Brasília, DF,13/09/1996, p.15.582. Disponível em: $<$ https://legislacao.presidencia.gov.br>. Acesso em: 23 out. 2020.

BRASIL. Senado Federal. Altera arts. $6^{\circ}$, 18, 20, 29-A, 37, 39, 48, 62, 68, 71, 74, 84, 163, 165, 166, $167,168,169,184,198,208,212,213$ e 239 da Constituição Federal e os arts. 35, 107,109 e 111 do Ato das Disposições Constitucionais Transitórias; acrescenta à Constituição Federal os arts. 135- A, 163-A, 164-A, 167-A, 167-B, 168-A e 245-A; acrescenta ao Ato das Disposições Constitucionais Transitórias os arts. 91-A, 115, 116 e 117. Projeto de Emenda Constitucional n. 188 de 05 de 
novembro de 2019. Brasília, DF, 05.11.2019. Disponível em: <https://legis.senado.leg.br >. Acesso em: 23 out. 2020.

BRASIL. Senado Federal. Tramitação Projeto de Emenda Constitucional n. 188/2019. Disponível em <https://www25.senado.leg.br/web/atividade/materias/-/materia/139704>. Acesso em: 25 out. 2020.

BRASIL. Tesouro Nacional. Sistema de informações contábeis e fiscais do setor público brasileiro - 2018. Disponível em $\leq$ https://siconfi.tesouro.gov.br/siconfi/pages/public/consulta_finbra/finbra_list.jsf $\geq$ Acesso em: 04 abr. 2020.

CERDÀ, Paco. Los últimos. Logroño (La Rioja): Pepitas de calabaza, 2017.

CIGOLINI, A. A. A fragmentação do território em municípios: um resgate histórico. Revista Paranaense de Geografia, Curitiba, n.5, p.55-65, 2000. https://doi.org/10.5380/raega.v5i1.18315

Território e criação de municípios: o significado teórico-político da compartimentação do espaço. Raega - 0 Espaço Geográfico em Análise, v. 25, 2012, p. 111-133. https://doi.org/10.5380/raega.v25i0.28006

COLLITS, Paul. Small Town Decline and Survival: Trends, Success Factors and Policy Issues. In: NATIONAL CONFERENCE ON THE FUTURE OF AUSTRALIA'S COUNTRY TOWNS, 1, 2000, Bendigo. Anais... Melbourne: La Trobe University, 2000. Disponível em: http://inform.regionalaustralia.org.au/process/managing -change/item/small-town-decline-and-survivaltrends-causes-and-policy-issues-4. Acesso em: $06 \mathrm{fev.} 2020$.

CONDE, R. La mitad de los pueblos de España está en riesgo de desaparición. El Mundo. Madrid. Demografia. Disponível

em: https://www.elmundo.es/espana/2018/01/27/5a6b9793468aebc5468b4696.html. Acesso em: 23 out. 2020.

ENDLICH, A. M. Desafios da escala local no Brasil. In: CUNHA, L.; PASSOS, M. M.; JACINTO, R. (Org.). As novas Geografias dos países de língua portuguesa. Guarda: Centro de Estudos lbéricos, 2010, p. 425-455.

Dinâmicas espaciais, contradições e perspectivas na relação cidade-campo. In: Patrícia Chame Dias, Brandão; Paulo Roberto Barqueiro. (Org.). Cidades médias e pequenas: dinâmicas espaciais, contradições e perspectivas na relação cidade-campo. Salvador: SEI, 2015, v. 1, p. 19-30.

Entre as pequenas cidades concretas e as utópicas: reflexões sobre o devir. In: Brandão, Paulo R.B. (Org.). Cidades Médias e Pequenas: Reflexões sobre Dinâmicas Espaciais Contemporâneas. Curitiba: Appris, 2019, v. 1, p. 15-37.

Escala e território: a perspectiva do município no Brasil. Scripta Nova. Revista Electrónica de Geografía y Ciencias Sociales. Barcelona: Universidad de Barcelona, 2012, vol. 16, n. 418.

Pensando os papéis e significados das pequenas cidades. São Paulo: Editora da Unesp, 2009. v. 1. 357 p.

Réquiem para as pequenas cidades? Geocritiq: Plataforma digital ibero-americana para la difusión del trabajo científico, Barcelona, p. 1 - 2, 10 out. 2013.

Sobre o município (Fundamentum). Maringá: Eduem, 2016, 43 p.

FERNANDES, André Luiz (coord.) e outros. Estudo de Viabilidade Municipal. Curitiba: Tribunal de Contas do Paraná, 2015. 127 p.

IBGE - Instituto Brasileiro de Geografia e Estatística. Mapas, 2015. Disponível em https://mapas.ibge.gov.br/bases-e-referenciais/bases-cartograficas/malhas-digitais. Acesso em: 16 nov. 2020.

Receitas e despesas públicas, 2018. Disponível em https://www.ibge.gov.br/estatisticas/economicas/financas -publicas. Acesso em: 23 out. 2020.

INDEC - Instituto Nacional de Estadísticas y Censos. Censo 2010. República Argentina. Disponível em <https://www.indec.gob.ar/>. Acesso em: 25 out. 2020. 
IPARDES - Instituto Paranaense de Desenvolvimento Econômico e Social. Perfil Avançado dos Municípios 2019. Disponível em http://www.ipardes.pr.gov.br/Pagina/Perfil-avancado-dos-municipios. Acesso em: 20 de maio 2020.

KLERING, L.R. Experiências recentes em municípios brasileiros: os novos municípios e as conquistas da autonomia. In: FACHIN, R.; CHANLAT, A. Governo municipal na América Latina: inovações e perplexidades. Porto Alegre: Sulina/Editora da Universidade UFRGS, 1998, p.248-265.

KROPOTKIN, P. EI Estado. Granada/Barcelona: Atlante, ¿191?, 107 p. (Los pequeños grandes libros, n.51-52).

LO NUNCA VISTO. Direção e Roteiro: Marina Seresesky. Madri/Espanha Tandem Films/TVE. Distribuição Netflix, 2019. 1 filme (93 min), son. col.

LOBATO, M. Cidades Mortas. São Paulo: Brasiliense, 1995, 243 p.

MEIRELLES, H. L. Direito municipal brasileiro. 17 ed. São Paulo: Malheiros, 2013. 870 p.

MENDES, M.; MIRANDA, R. B.; COSIO, F. B. Transferências Intergovernamentais no Brasil: diagnóstico e proposta de reforma. Textos para discussão 40. Brasília: Consultoria Legislativa do Senado Federal. 2008.

MOLINO, Sergio del. La España vacía: viaje por un país que nunca fue. Madrid: Turner, 2016.

ORDUÑA REBOLLO, E. Municípios y Províncias: Historia de la organización territorial española . Madrid: Federación Española de Municípios y Provincias; 2003, 789 p.

POSADA, A. Escritos municipalistas y de la vida local. Madrid: Instituto de Estú

dios de Administración Local, 1979, 493 p. (Série Administración y ciudadano, 7).

SANTOS, A. S. P. Município, descentralização e território. Rio de Janeiro: Editora Forense. 2008. $248 \mathrm{p}$.

SANTOS, D. C. A criação de municípios na década de 1990 no Vale do Ivaí: implicações socioespaciais. 2020. Dissertação (Mestrado em Geografia). Universidade Estadual de Maringá, Maringá.

SOUZA, A. D. Novos municípios como espaços sociais e políticos. 2016. Tese (Doutorado em Geografia). Universidade Estadual de Maringá, Maringá

Recebido em:01/07/2020

Aceito para publicação em: 16/11/2020 